\title{
Teachers' perspectives on professional learning communities in some Arab countries
}

\author{
Al-Mahdy, Yasser F. Hendawy \\ Faculty of Education, Ain Shams University, Egypt (y_fathy1975@yahoo.com) \\ Sywelem, Mohamed M. Ghoneim \\ Faculty of Education, Suez University, Egypt (ghoneim23@ gmail.com)
}

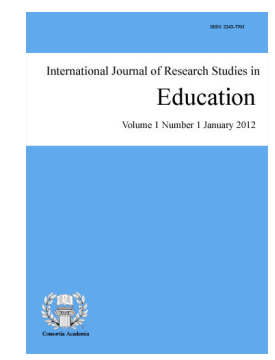

ISSN: 2243-7703 Online ISSN: 2243-7711

Received: 22 October 2015

Revised: 14 November 2015 Available Online: 31 January 2016 DOI: $10.5861 /$ ijrse.2016.1349

Accepted: 29 November 2015

OPEN ACCESS

\section{Abstract}

The purpose of this study is to assess the perceptions of public school teachers in three Arab countries (Egypt, Saudi Arabia \& Oman) based on the dimensions of Professional Learning Communities (PLCs) and related attributes. A quantitative approach is implemented using the Professional Learning Communities Assessment-Revised (PLCA-R) questionnaire developed by (Olivier; Hipp, \& Huffman, 2010). The measure is administered to public school teachers in Egypt, KSA, and Oman. The PLCA-R utilizes a four-point, forced Likert Scale. A sample of (1486) subjects is selected during 2014-2015 school years. The data is analyzed through descriptive statistics. The research concluded that both Saudi and Omani teachers showed positive perceptions regarding the degree to which their schools function as PLCs; whereas Egyptians showed negative perceptions, and there were significant differences between male and female teachers regarding their perceptions of the degree to which their schools function as PLCs in favor of female teachers.

Keywords: professional learning communities; teachers' perspectives; Egypt; Saudi Arabia; Oman 


\section{Teachers' perspectives on professional learning communities in some Arab countries}

\section{Introduction}

Over the last two decades many school districts have developed professional learning communities (PLCs) as a means of unifying teachers within school organizations toward common goals and collaborative efforts (Gray, 2011). The idea of a learning community is embedded in Senge's research on the concept of a learning organization "where people continually expand their capacity to create the results they truly desire, where new and expansive patterns of thinking are nurtured, where collective aspiration is set free, and where people are continually learning how to learn together" (Senge, 1990, p. 3). Much of the literature on PLCs is grounded in theories that highlight the social nature of learning and detail practices through which teachers share and build their work (Feger, Arruda, Pringle, \& Briggs, 2008). Researchers agree that PLCs are important for improved student achievement. Dennis Sparks, the executive director of the National Staff Development Council (NSDC) urges schools to recognize that "professional learning communities are indeed the best form of staff development” (in Schmoker, 2006, pp. 108-109).

Vescio and Adams (2008) indicate that "Learning communities are grounded in two assumptions. First, knowledge is situated in the day-to-day lived experiences of teachers and best understood through critical reflection with others who share the same experience. Second, actively engaging teachers in PLCs will increase their professional knowledge and enhance student learning" (p. 81). The ultimate goal of PLCs can be summed up in three words: improved student achievement (DuFour, DuFour, \& Eaker, 2008). Little (2002) states that each of the words making up the phrase "professional learning community" brings their own meaning. The word "professional" suggests a specialized and technical knowledge base, and a service-oriented member who meets client needs, having a strong collective identity to a practice; the word "learning" in context, involves working together towards a common understanding, and the word "community" refers to a group of individuals who share a common mission, values, goals, and experiences to accomplish a task.

Bolam et al. (2005) argue that "the key purpose of professional learning communities is to enhance staff effectiveness as professionals, for the ultimate benefit of students" (p. 10). Hefner (2011) adds that PLCs seem to fit the need of educational leaders searching for strategies to improve their institutions. The current paper is embedded in the research aforementioned, and it focuses on examining the dimensions and critical attributes forming the professional learning community from teachers' views in three Arab countries (Egypt, KSA, \& Oman).

\section{Review of Literature}

\subsection{Concept of PLCs}

The term "Professional Learning Community" has many definitions. Stoll, Bolam, McMahon, Wallace, and Thomas (2006) assure that there is no universal definition of PLCs. According to Pancake and Moller (2002) this term is used to describe a school committed to achieving a culture of collective learning and creativity that is characterized by: shared values and vision; supportive and distributed leadership; collaborative professional norms; an enquiry orientation; and facilitative organizational conditions. DuFour, DuFour, Eaker, and Many (2006) add that PLCs are defined as communities of educators committed to working collaboratively in ongoing processes of collective inquiry and action research to achieve better results for the students they serve. PLCs operate under the assumption that the key to improved learning for students is continuous, job-embedded learning for educators. Burnett (2002) concludes that a professional learning community is a "school where people are united by a common purpose, shared vision, collective commitments, and specific, measurable goals; 
where collaborative teams engage in action research and collective inquiry into the big questions of teaching and learning; where continuous improvement cycles are built into the routine practices of the school; and where gathering evidence of student learning is a constant focus" (p. 52). Although the term has grown to encompass a wide variety of concepts and practices, a PLC always represents a collective effort to enhance student learning, promotes and sustains the learning of all professionals in the school, builds knowledge through inquiry, analyses and uses data for reflection and improvement (Literacy and Numeracy Secretariat, 2007).

\subsection{Characteristics of Effective PLCs}

Stoll and Louis (2007) argue that the focus of PLCs is not just on individual teachers' learning but on (1) professional learning; (2) within the context of a cohesive group; (3) that focuses on collective knowledge, and (4) occurs within an ethic of interpersonal caring that permeates the life of teachers, students and school leaders. DuFour et al. (2008) add that the goal of a PLC is to create a condition for perpetual learning. This creates an environment in which innovation and experimentation are not viewed as tasks to be accomplished or projects to be completed, but as ways of conducting day-to-day business forever. Furthermore, participation in this process is not reserved for those designated as leaders: instead, it is a responsibility of every member of the organization.

Bryk, Camburn, and Louis (1999) have discerned three essential characteristics of PLCs which include "reflective dialogue among teachers about instructional practices and student learning, a deprivatization of practice in which teachers observe each other's practices, and joint problem solving is modal and peer collaboration in which teachers engage in actual shared work" (p. 753). Newmann (1996) describe five essential characteristics of PLCs 1) shared values and norms; 2) clear and consistent focus on student learning; 3) reflective dialogue; 4) deprivatizing practice to make teaching public; and 5) focusing on collaboration. DuFour et al. (2006) have showed four pillars of PLCs 1) mission; 2) vision; 3) values; and 4) goals, and have raised four key questions for PLCs to address 1) why do we exist? 2) What must we become to accomplish our purpose? 3) How must we behave to achieve this vision? 4) How will we mark our progress?

The framework of a PLC model can be put into three themes; the school has to have a solid, shared mission, vision, values, and goals; collaborative teams that work interdependently to achieve common goals; and a focus on results as evidenced by a commitment to continuous improvement (Eaker, DuFour, \& DuFour, 2002).

\subsection{Dimensions of PLCs}

PLCs, as described in the literature, appear to support five key dimensions: shared leadership, shared vision, collective creativity and learning, peer review or shared personal practice, and supportive conditions/capacities (Cowley, 1999; Hord \& Sommers, 2008).

Shared and supportive leadership - One of the defining characteristics of a PLC is that authority and decision-making are shared. Hipp and Huffman (2002) indicate that "shared leadership involves school administrators sharing power and authority, inviting input into decision-making, and promoting and nurturing leadership among staff" (p. 29). Hord (1995) further concludes that supportive and shared leadership requires that all stakeholders are empowered by administrators to make decisions that affect the community. In addition, Ciurysek, Handsaeme, Palko, Sterling, and Toth (2012) assure that when leadership is shared among teachers and other community members, they will feel more ownership of and commitment to decisions and actions. In her discussion of teacher leadership, Harris (2003) concluded:

"If we are serious about building professional learning communities within and between schools then we need forms of leadership that support and nourish meaningful collaboration among teachers. This will not be achieved by clinging to models of leadership that, by default rather than design delimits the possibilities for teachers to lead development work in schools" (p. 322). 
Likewise, Morrissey (2000) encourages principals to communicate their belief in PLCs to all stakeholders and create structures that ensured the sharing of leadership and decision-making. In addition, Stoll et al. (2006) urge principals to distribute leadership by providing teachers with opportunities to take leadership roles related to teaching and learning. In such a model, administrators, along with teachers try to find solutions for school improvement. This new relationship forged between administrators and teachers leads to a shared and collegial leadership in the school, where all grow professionally and learn to view themselves as "all playing on the same team and working toward the same goal: a better school" (Hord, 2007, p. 16).

Shared values and vision - Professional learning communities are founded on a strong foundation that is built on shared values and vision (Morrow, 2010). A school's vision statement outlines what the organization aspires to become. It should offer motivation and hope for a community that is working towards attaining an ideal. And a school's value statements outline what the community members are committed to in order to ensure school improvement (Ciurysek et al., 2012). In this context, Hefner (2011) argues that having shared vision enables individuals to work productively as a group toward a common goal. This common goal in professional learning communities focuses mainly on students' learning and achievement.

Sharing vision is not just agreeing with a good idea; it is a particular mental image of what is important to an individual and to an organization. The shared values and vision among school staff guide decisions about teaching and student learning, and support norms of behavior (Morrissey, 2000). In addition, Hord (1997) argues that "staff is encouraged not only to be involved in the process of developing a shared vision, but to use that vision as a guidepost in decision making about teaching and learning in the school" (p. 19). Hipp and Huffman (2002) further conclude that administrators must have the capacity to develop and unite the stakeholders under the umbrella of a shared vision.

Collective learning and application - PLCs engage school staff at all levels in processes that collectively seek new knowledge and ways of applying that knowledge to their work (Morrissey, 2000). In her research, Hefner (2011) assures that collaboration is a key component of a PLC. Leonard and Leonard (2003) add that collaboration is widely promoted as critical to the development of schools as PLCs. Moreover, Hord (1995) recognizes that "such collaborative work is grounded in reflective dialogue or inquiry, where staff members conduct conversations about students and teaching and learning, identifying related issues and problems" (p. 9). Collaboratively and collectively, teachers engage in reflective dialogue about the data in an effort to enhance, modify and change the instructional program (Morrow, 2010). According to the findings of their research, Hipp and Huffman (2003) assure that as teachers shared information and developed processes whereby they could work collaboratively, they became more successful in applying strategies that worked well for students.

Shared personal practice - Sharing personal practice requires a complete paradigm shift from traditional roles in education (Morrissey, 2000). Hord (1995) considers shared personal practice as a critical attribute of a PLC because it provides colleagues with the opportunities to obtain support, feedback, and constructive criticism from their peers in a risk free environment. In addition, Huffman and Hipp (2003) argue that within the framework of shared personal practice, peer observations are conducted as a strategy for offering suggestions, knowledge, and encouragement. Hefner (2011) adds that engaging teachers in PLCs will increase individual and organizational capacities; as PLCs promote group and individual learning through peer reviews and feedback pertaining to teachers' instructional practices. In this context, Morrow (2010) assures that "professional growth for teachers is a direct result of shared personal practice because of the continuous sharing of knowledge that occurs between colleagues" (p. 40).

Supportive conditions - Supportive conditions determine when and where and how the staff regularly comes together as a unit to do the learning, decision making, problem solving, and creative work that characterize a PLC (Hord, 1997, p. 20). To establish an environment that promotes continuous sharing between colleagues, supportive conditions must be established and sustained (Huffman \& Hipp, 2003). In addition, Hord (1997) cites two types of supportive structures found within PLCs: structural conditions and collegial relationships. The 
structural conditions include use of time, communication procedures, size of the school, proximity of teachers, and staff development processes. Collegial relationships include positive educator attitudes, widely shared vision or sense of purpose, norms of continuous critical inquiry and improvement, respect, trust, and positive, caring relationships. Morrissey (2000) also argued that structures that support the vision of a school and learning community are vital to the effectiveness and innovation of teaching at the classroom level.

\subsection{Problem of the Study}

Literature, mentioned above, indicates a necessity of PLCs for improving school performance, and school effectiveness. Although the international research on PLCs is wide and deep; there is scarcity of research on this issue in the Arab world, which is evident in the literature review that draws upon the significant works in Western literature, but has found poor work on the Arab context. There are no previous studies, in the Arab context, investigated teachers' perceptions regarding the key dimensions which constitute a professional learning community and whether or not the existing climate within schools has an effect on making such a professional learning community. The purpose of this study is to explore teachers' perceptions in three Arab countries (Egypt, Saudi Arabia, \& Oman) based on PLCs dimensions and related attributes. The study is designed to figure out whether or not there are significant differences among teachers' perceptions based on the dimensions of The Professional Learning Communities Assessment - Revised (PLCA-R) Questionnaire.

\subsection{Research Questions}

The study tries to answer the following research questions:

$>\quad$ What are teachers' perceptions regarding the dimensions of The PLCA-R in the three Arab countries?

$>\quad$ To what extent, if any, are there significant differences among Egyptian, Saudi \& Omani teachers regarding the dimensions of the PLCA-R?

$>\quad$ To what extent, if any, are there significant differences among male $\&$ female teachers regarding the dimensions of the PLCA-R?

\section{Methods}

\subsection{Instrument}

This study is quantitative correlational in nature. In order to identify teachers' perceptions regarding the key dimensions which constitute a professional learning community, the Professional Learning Communities Assessment - Revised (PLCA-R) Questionnaire by Olivier, Hipp, and Huffman (2010) was used. The researchers asked permission from the authors to use the PLCA-R Questionnaire, Dr. Diane Olivier, a research colleague of the authors designated to respond to requests for the use of the instrument, granted permission. For Arab participants, the PLCA-R Questionnaire was translated into Arabic. This Arabic version was constructed in the same format as the English version, and was given to two language experts for back translation. A corrected final version of the questionnaire was administered to a group of public school teachers in Saudi Arabia, Egypt \& Oman. Purposely, the PLCA-R provides perceptions of the staff relating to specific practices observed at the school level with regard to five dimensions: shared and supportive leadership, shared values and vision, collective learning and application, shared personal practice, and supportive conditions, including both relationships and structures. The PLCA-R utilizes a four-point, forced Likert scale ranging from $1=$ Strongly Disagree to $4=$ Strongly Agree. The statements of the survey are categorized into representative groups:

> Items 1-11 focus on the attributes supporting Shared and Supportive Leadership

$>$ Items 12-20 assess Shared Values and Vision

$>$ Items 21-30 determine the participants' perceptions in regards to Collective Learning and Application.

$>\quad$ Items 31-37 assess the Shared Personal Practice

$>\quad$ Items 38-42 pertain to Supportive Conditions- Relationships

$>\quad$ Items 43-52 pertain to Supportive Conditions- Structures (Olivier, Hipp, \& Huffman, 2010). 
Al-Mahdy, Y. F. H., \& Sywelem, M. M. G.

The internal consistency of the variables was analyzed using Cronbach's alpha. Table (1) illustrates the results of internal consistency analysis, in the Arabic version of the questionnaire:

\section{Table 1}

Internal Consistency Analysis for PLCA-R

\begin{tabular}{lccccccc}
\hline \multicolumn{1}{c}{ Subscales PLCA-R Subscales } & $\begin{array}{c}\text { Cronbach's } \\
\text { Alpha }\end{array}$ & 1 & 2 & 3 & 4 & $5 \mathrm{~A}$ & $5 \mathrm{~B}$ \\
\hline Shared and Supportive Leadership & 0.930 & 1 & & & & \\
Shared Values and Vision & 0.931 & $.751^{* *}$ & 1 & & & \\
Collective Learning and & 0.949 & $.757^{* *}$ & $.902^{* *}$ & 1 & & & \\
Application & & & & & & & \\
Shared Personal Practice & 0.938 & $.720^{* *}$ & $.857^{* *}$ & $.902^{* *}$ & 1 & & \\
Supportive & 0.955 & $.733^{* *}$ & $.875^{* *}$ & $.905^{* *}$ & $.886^{* *}$ & 1 & \\
Conditions-Relationships & & & & & & & \\
Supportive Conditions-Structures & 0.928 & $.588^{* *}$ & $.770^{* *}$ & $.812^{* *}$ & $.784^{* *}$ & $.814^{* *}$ & 1 \\
One Factor Solution & 0.985 & $.835^{* *}$ & $.938^{* *}$ & $.962^{* *}$ & $.931^{* *}$ & $.940^{* *}$ & $.877^{* *}$ \\
\hline
\end{tabular}

\subsection{Participants}

The researchers applied stratified sampling. Strata were initially selected based on the type of schools. In Egypt, 30 public schools were selected randomly and included 21 male and 9 female schools. The researchers sent 25 surveys to each school totaling 750. The surveys were given to 525 male and 225 female teachers randomly chosen by the principal from the nine different grade levels. 509 teachers (423 males and 86 females) responded to the survey, which corresponds to a response rate of $67.9 \%$.

In Oman, 34 public schools were selected randomly and included 11 male and 23 female schools. The researchers sent 25 surveys to each school totaling 850 . The surveys were given to 275 male and 575 female teachers randomly chosen by the principal from the nine different grade levels. 726 teachers (194 males and 532 females) responded to the survey, which corresponds to a response rate of $85.4 \%$.

In Saudi Arabia, 25 public schools were selected randomly and included 13 male and 12 female schools. The researchers sent 20 surveys to each school totaling 500. The surveys were given to 260 male and 240 female teachers randomly chosen by the principal from the nine different grade levels. 251 teachers (132 males and 119 females) responded to the survey, which corresponds to a response rate of $50.2 \%$. Table (2) depicts a representation of the participants chosen for the study.

Table 2

Participants' Demographics

\begin{tabular}{lcccc}
\hline \multicolumn{1}{c}{ Nationality } & Male & Female & Total & Percent \\
\hline Egyptian & 423 & 86 & 509 & $34.2 \%$ \\
Omani & 194 & 532 & 726 & $48.9 \%$ \\
Saudi & 132 & 119 & 251 & $16.9 \%$ \\
Total & 749 & 737 & 1486 & $100 \%$ \\
\hline
\end{tabular}

Note. $\mathrm{N}=1486$

\section{Findings}

The purpose of this study was to determine public school teachers' perceptions of the degree to which their schools function as PLCs, and to determine whether or not there were significant differences among Egyptian, Saudi, and Omani teachers in this regard. Finally, the study examined if there were significant differences based on teachers' gender. This was a quantitative study using descriptive statistical analysis to address three research questions. 
$Q .1$. What are teachers' perceptions based on the dimensions of The PLCA-R in the three Arab countries?

To address this question, table (3) displays the descriptive statistics for all responses of (1486) teachers on the dimensions of The PLCA-R. Participants responded to 52 statements on the PLCA-R questionnaire based on their level of agreement ( 1 = Strongly Disagree, $2=$ Disagree, $3=$ Agree, $4=$ Strongly Agree). Mean scores were calculated for the overall response and for each dimension of PLCA-R questionnaire.

\section{Table 3}

Questionnaire Overall and Dimension Mean Scores

\begin{tabular}{lccccccc}
\hline $\begin{array}{c}\text { All } \\
\text { Responses }\end{array}$ & Overall & $\begin{array}{c}\text { Shared } \\
\text { and } \\
\text { Supportive } \\
\text { Leadership }\end{array}$ & $\begin{array}{c}\text { Shared } \\
\text { Values } \\
\text { and } \\
\text { Vision }\end{array}$ & $\begin{array}{c}\text { Collective } \\
\text { Learning and } \\
\text { Application }\end{array}$ & $\begin{array}{c}\text { Shared } \\
\text { Personal } \\
\text { Practice }\end{array}$ & $\begin{array}{c}\text { Supportive } \\
\text { Conditions } \\
\text { Relationships }\end{array}$ & $\begin{array}{c}\text { Supportive } \\
\text { Conditions } \\
\text { Structures }\end{array}$ \\
\hline Mean & 2.79 & 2.93 & 2.78 & 2.81 & 2.73 & 2.85 & 2.62 \\
SD & 0.69 & 0.69 & 0.74 & 0.77 & 0.78 & 0.81 & 0.83 \\
\hline
\end{tabular}

Note. $\mathrm{N}=1486$

Table (3) contains the overall questionnaire mean scores and individual dimension mean scores by all respondents participating in the study. Based on the compilation of means for all respondents to the survey, the overall mean score is $(\mathrm{M}=2.79)$. Table (3) displays mean scores for individual dimension ranging from the lowest rated dimension ( $\mathrm{M}=2.62)$ for Supportive Conditions-Structures to The highest rated dimension $(\mathrm{M}=2.93)$ for Shared and Supportive Leadership. The other dimension mean scores for all responses are $(\mathrm{M}=2.78)$ for the dimension of Shared Values and Vision, $(M=2.81)$ for the dimension of Collective Learning and Application, $(M=2.73)$ for the dimension of Shared Personal Practice, $(M=2.85)$ for the dimension of Supportive Conditions Relationships. Table (3) shows that the Arab teachers have medium mean scores overall and in all six dimensions of the questionnaire.

Data from this table are significant because they tell us that public school teachers in Egypt, KSA, and Oman feel that their schools need more time and efforts to function as PLCs. Dimensions: Supportive Conditions-Structures $(M=2.62)$ and Shared Personal Practice $(M=2.71)$ were the lowest rated dimensions, this indicates that the structure conditions of public schools in the three Arab countries are not supportive for schools to functions as PLCs, according to the number of teachers' responses given to these dimensions. Also teachers feel that these unsupportive conditions don't encourage them to work collaboratively. Wells and Feun's (2007) findings from a separate study of six high schools that initiated learning communities indicated that the schools struggled and that teachers were not trained to work together. On the other hand, these data reveal that Shared and Supportive Leadership had the highest mean score $(\mathrm{M}=2.93)$, compared to the other dimensions, this may due to overload of work and responsibilities of school principals which urge them to have shared responsibility. In her research about PLCs in the United Arab Emirates Schools, Al-Taneiji (2009) concluded that Data from the questionnaire revealed that out of six PLC characteristics, only two characteristics were exhibited by the fifteen Emirates schools: a) supportive and shared leadership, and b) supportive structure.

Duling (2012) and Bertsch (2012) support this finding, revealing, the highest ranked dimension is shared and supportive leadership, according to the number of responses given to the open-ended question. This finding reinforces the value of principal leadership. In agreement with this finding, Aylsworth (2012) suggested that administrators preparing to implement PLCs should consider a supportive, collaborative leadership style that involves staff in the decision-making process.

\section{Q.2. To what extent, if any, are there significant differences among Egyptian, Saudi and Omani teachers} regarding the dimensions of the PLCA-R?

To address this question, SPSS software was utilized to perform one-way analysis of variance (ANOVA) and report the findings, and a post hoc analysis was conducted to compare and analyze mean scores from the PLCA-R questionnaire to determine which mean raw score ratings were different. 
Al-Mahdy, Y. F. H., \& Sywelem, M. M. G.

\section{Table 4}

One-way ANOVA for PLCA-R by Nationality

\begin{tabular}{|c|c|c|c|c|c|c|c|c|}
\hline \multirow{2}{*}{ PLC Dimensions } & \multicolumn{2}{|c|}{ Egypt } & \multicolumn{2}{|c|}{ Oman } & \multicolumn{2}{|c|}{ KSA } & \multirow{2}{*}{$\mathrm{F}$} & \multirow{2}{*}{ Sig* } \\
\hline & $\mathrm{M}$ & SD & $\mathrm{M}$ & SD & $\mathrm{M}$ & $\mathrm{SD}$ & & \\
\hline Shared and Supportive & 2.72 & 0.84 & 3.01 & 0.55 & 3.15 & 0.55 & $45.33 * *$ & 0.00 \\
\hline Leadership & & & & & & & & \\
\hline Shared Values and Vision & 2.36 & 0.83 & 3.00 & 0.58 & 3.00 & 0.54 & $150.51 * *$ & 0.00 \\
\hline $\begin{array}{l}\text { Collective Learning and } \\
\text { Application }\end{array}$ & 2.34 & 0.89 & 3.04 & 0.58 & 3.08 & 0.54 & $172.98 * *$ & 0.00 \\
\hline Shared Personal Practice & 2.19 & 0.78 & 2.99 & 0.62 & 3.08 & 0.62 & $244.89 * *$ & 0.00 \\
\hline Supportive Conditions & 2.36 & 0.91 & 3.07 & 0.62 & 3.20 & 0.57 & $176.69 * *$ & 0.00 \\
\hline Relationships & & & & & & & & \\
\hline Supportive Conditions Structures & 2.05 & 0.90 & 2.93 & 0.59 & 2.89 & 0.64 & $245.93 * *$ & 0.00 \\
\hline
\end{tabular}

As shown in Table 4, there were statistically significant differences among the three Arab countries regarding the existence of the first dimension (Shared and Supportive Leadership) in favor of KSA, and there were significant differences between Egypt and the two Gulf countries (KSA \& Oman) regarding the existence of all PLC dimensions in favor of Gulf countries, but there were no significant difference between KSA and Oman regarding all dimensions except two dimensions (Shared and Supportive Leadership, Supportive Conditions-Relationships) which were in favor of KSA. This is better illustrated in Figure (1), which contains a bar diagram of means on the six PLC dimensions. The results showed that the perceptions of Saudi teachers have higher means in most dimensions of PLC, while the responses of Egyptian teachers have the lowest means in all dimensions.

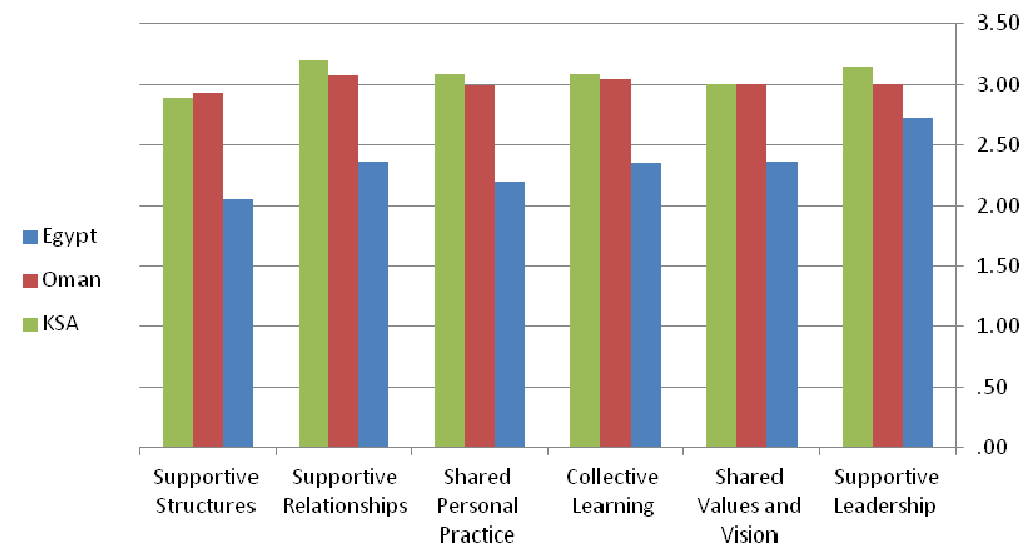

Figure 1. Differences among Egyptian, Saudi, and Omani teachers in relation to the six PLC dimensions

With respect to the first dimension, supportive and shared leadership, there were statistically significant differences among groups $(\mathrm{F}=45.33, \mathrm{p}=.01)$ for $\mathrm{KSA}$; shared values and vision was statistically significant between Oman and Egypt in favor of Oman, between KSA and Egypt in favor of KSA $(\mathrm{F}=150.51, \mathrm{p}=.01)$, and wasn't statistically significant between KSA and Oman $(\mathrm{p}=.998)$; collective learning and application was statistically significant between Oman \& Egypt in favor of Oman, between KSA \& Egypt in favor of KSA (F = $172.98, \mathrm{p}=.01)$, and wasn't statistically significant between KSA and Oman $(\mathrm{p}=.736)$; shared personal practice was statistically significant between Oman and Egypt in favor of Oman, between KSA and Egypt in favor of KSA ( $F=244.89, p=.01)$, and wasn't statistically significant between KSA and Oman $(\mathrm{p}=.170)$; supportive relationships were statistically significant $(\mathrm{F}=176.69, \mathrm{p}=.01)$ for $\mathrm{KSA}$; and supportive structures were statistically significant between Oman and Egypt in favor of Oman, between KSA and Egypt in favor of KSA (F $=245.93, \mathrm{p}=.01)$, and weren't statistically significant between KSA and Oman $(\mathrm{p}=.759)$. 
Teachers' perspectives on professional learning communities in some Arab countries

Q. 3. To what extent, if any, are there significant differences among Male \& Female teachers regarding the

dimensions of the PLCA-R?

Table 5

T-tests for PLCA-R by Gender

\begin{tabular}{|c|c|c|c|c|c|c|c|}
\hline \multirow{2}{*}{ PLC Dimensions } & \multicolumn{2}{|c|}{ Male teachers } & \multicolumn{2}{|c|}{ Female teachers } & \multirow{2}{*}{ T-Value } & \multirow{2}{*}{ Df } & \multirow{2}{*}{$\mathrm{P}$} \\
\hline & $\mathrm{M}$ & SD & $\mathrm{M}$ & SD & & & \\
\hline Shared and Supportive Leadership & 2.86 & 0.80 & 3.01 & 0.53 & -4.11 & 1484 & $0.00 * *$ \\
\hline Shared Values and Vision & 2.58 & 0.83 & 2.99 & 0.56 & -11.01 & 1484 & $0.00 * *$ \\
\hline Collective Learning and Application & 2.60 & 0.90 & 3.02 & 0.55 & -10.87 & 1484 & $0.00 * *$ \\
\hline Shared Personal Practice & 2.52 & 0.85 & 2.95 & 0.63 & -10.90 & 1484 & $0.00 * *$ \\
\hline Supportive Conditions Relationships & 2.64 & 0.90 & 3.06 & 0.93 & -10.31 & 1484 & $0.00 * *$ \\
\hline Supportive Conditions Structures & 2.33 & 0.93 & 2.92 & 0.58 & -14.60 & 1484 & $0.00 * *$ \\
\hline
\end{tabular}

As shown in Table 5, the (T) value is statistically significant. This indicates that there were statistically significant differences between male and female teachers regarding the dimensions of the PLCA-R in favor of female teachers. Thus, the answer to the third question is: There are statistically significant differences at $(0.01)$ level between male and female teachers in the three Arab countries regarding the dimensions of the PLCA-R in favor of female teachers.

The findings of Klieme and Vieluf (2009) supported this finding, revealing that female teachers are more likely than male teachers to adopt structuring and student oriented practices as well as to co-operate more with colleagues, they are more often involved in co-operative activities (p. 113). In addition, Taylor (2011) argued that female teachers seem to be slightly more likely than male teachers to take professional development opportunities. Male teachers were found to have lower perception scores compared to female teachers. Female teachers had significantly higher levels of agreement on the PLC questionnaire. This is better illustrated in Figure (2), which contains a bar diagram of means on the six PLC dimensions. The results showed that the perceptions of female teachers have higher means in all dimensions of PLC than male teachers.

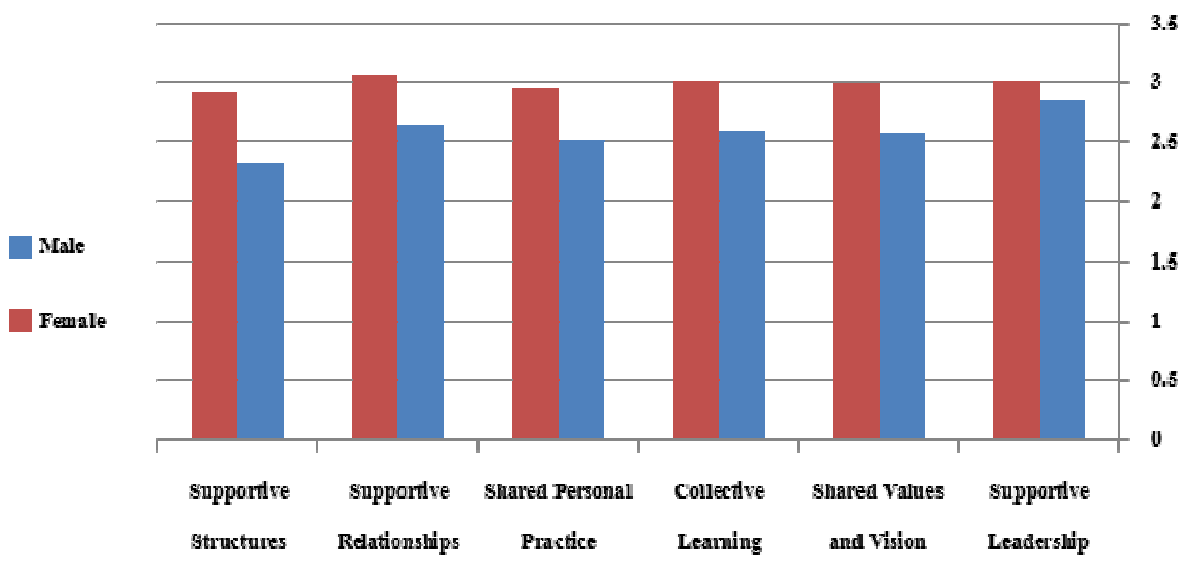

Figure 1. Differences between male and female teachers in relation to the six PLC dimensions

\section{Discussion}

This study sought to figure out teachers' perceptions about the extent to which Saudi, Omani, and Egyptian public schools function as PLCs. The results of the survey indicated that not all characteristics of the PLC existed in the Egyptian schools. Only supportive and shared leadership was evident in these schools. On the other hand, the results of the survey indicated that all characteristics of the PLC existed to somewhat (medium level of agreement) in Omani and Saudi schools. This result is consistent with the results of some previous 
studies and reports (Hartmann, 2008; OECD, 2010; Unesco, 2010; Loveluck, 2012; Menshawy, 2012; and krafft, 2012) which showed that the Egyptian Education System suffer from many problems, such as: Highly centralized system regarding administration, curriculum and examination; Poor quality of state-provided schooling; Shortages of qualified teachers; Shortage of school buildings and equipments; Inequality in distributing the educational resources; Students' dissatisfaction with the educational system because of pedagogical problems, poor treatment by teachers, and the difficulty of subjects; Teachers' dissatisfaction with the teaching profession as a result of poor salaries and low social status; limited freedom for teachers to structure the progress of their classes; the spread of private tutoring to supplement teachers' monthly salaries; increasing class size, the average class size was estimated at 42.7 pupils per class (up to a maximum of 50.1 in Alexandria for example); beside steering students towards memorization and rote-learning.

With regard to the survey findings, the perceptions of Omani and Saudi teachers were shown to have higher means in all the professional learning community dimensions than Egyptian teachers. This might be related to the nature of work conditions in both Oman and KSA such as: less average hours per week for instruction, less average of class size, higher average of salary, more supportive leadership, more positive relationships among teachers, less paperwork, and more access to technology. This conclusion was supported by the findings of many studies and reports (Al-Neimi \& Amzat, 2012; AlGhafri, 2002; Alnabhani, 2007; Alaqeel, 2005, Alharbi, 2011).

\section{Conclusion}

Research confirms that professional learning communities are the best form of staff development. This study concluded that the Egyptian schools don't function as professional learning communities based on teachers' perceptions, whereas the Saudi \& Omani schools function, to somewhat, as professional learning communities based on Saudi and Omani teachers' perceptions. In Egypt, this may due to the shortage of equipments and recourses which schools need. In general teachers in the Arab context are not involved in the planning process, teachers are not provided with effective training on implementing team work, a culture for learning and willingness to collaboration do not prevail, or a rewarding system does not exist (see Ibrahim, Al-Kaabi, \& El-Zaatari, 2013). In addition, the absence of sharing practices among teachers which is considered as an obstacle in front of improving school performance, as teachers will not be able to get benefit from the expertise of one another. As a result of the scarcity of research on PLCs in the Arab context, this study is expected to contribute PLCs literature by identifying public school teachers' perceptions of PLCs in Egyptian, Saudi and Omani Elementary Schools.

\subsection{Recommendations}

In reference to the implications of this study, it recommends that Educational Policymakers in Egypt, Oman \& Saudi Arabia should mentor and guide schools to focus on improving student achievement, and enhance teacher professionalism through increasing the professional status of teaching and providing teachers with greater opportunities for professional growth. School principals should promote the climate of trust and respect among teachers, and students. In this context, Hipp and Huffman (2003) assured that "without a climate of trust and respect, and structures that promote continual learning, it is impossible to build a professional learning community". In addition, school principals should involve all staff in decision making and in creating and maintaining school vision and values, and they should also provide teachers with information and resources and help them to grow professionally. Leithwood and Riehl (2003) and Youngs (2002) reported that school principals should be responsible for creating structures that promote teacher learning by focusing on how the task should be done and the time and the space that should be provided. On one hand, teachers have to change their traditional practices of teaching; they should perceive themselves to be professionals and expect to be respected as such. They should work collaboratively to apply strategies that worked well for students. In order to improve their classroom practice, teachers should work together and work in teams engaging in an ongoing cycle of collaboration that promote deep team learning. This process, in turn, leads to higher levels of student achievement. On the other hand, Students' Parents should be in connection with the school, they should attend regularly 
school meetings at which parents, counselor, and classroom teacher discuss student's learning and what each party will do to help the student meet the standards for the achievement.

Note: Some parts of the earlier version of this paper has been accepted and scheduled to be presented at the 38th Annual Eastern Educational Research Association Conference at the Hyatt Regency Sarasota, Florida on February 25-28, 2015.

\section{References}

Al Nabhani, M. (2007). Developing the education system in the Sultanate of Oman through implementing total quality management - The ministry of education central headquarters: A case study. Unpublished Doctoral dissertation, University of Glasgow, UK.

Alaqeel, A. (2005). Education policy and system in Saudi Arabia [in Arabic]. Riyadh: Al-Rushd Library.

AlGhafri, H. (2002). The impact of national development plans on the system of education in the sultanate of Oman: A study of the development and transformation of Omani society 1970-2000. Unpublished Doctoral dissertation, University of Exeter, UK.

Alharbi, A. (2011). The development and implementation of a CPD program for newly qualified teachers in Saudi Arabia. Unpublished Doctoral dissertation, University of Southampton, UK.

Al-Neimi, R. K., \& Amzat, I. H. (2012). Teachers' perceptions of their job satisfaction and turnover: A case study of some schools in Sultanate of Oman. OIDA International Journal of Sustainable Development, 3(9), 93-104.

Al-Taneiji, S. (2009). Professional learning communities in the United Arab Emirates schools: Realities and obstacles. International Journal of Applied Educational Studies, 6(1), 16-29.

Aylsworth, A. J. (2012). Professional learning communities: An analysis of teacher participation in a PLC and the relationship with student academic achievement. Unpublished Doctoral dissertation, Iowa state university, USA.

Bertsch, C. C. (2012). Perceptions of supportive leadership behaviors for professional learning communities in secondary schools. Unpublished Doctoral dissertation, California State University, Fullerton, USA.

Bolam, R., McMahon, A., Stoll, L., Thomas, S., Wallace, M., Greenwood, A., Hawkey, K., Ingram, M., Atkinson, A. \& Smith, M. (2005). Creating and sustaining effective professional learning communities. Retrieved from http://www.educationscotland.gov.uk/Images/Creating\%20and\%20Sustaining\%20PLCs_tcm4-631034. pdf

Bryk, A., Camburn, E., \& Louis, K. S. (1999). Professional community in Chicago elementary schools: Facilitating factors and organizational consequences. Educational Administration Quarterly, 35(5), 751-781. http://dx.doi.org/10.1177/0013161X99355004

Burnette, B. (2002). How we formed our community. National Staff Development Council, 23(1), 51-54. Retrieved from http://www.wisconsinpbisnetwork.org/assets/files/East\%20Region/07\%20how\%20we\%20formed\%200 ur\%20community_collective\%20commitments\%20article.pdf

Ciurysek, S., Handsaeme, S., Palko, L., Sterling, S., \& Toth, W. (2012). Professional learning communities: A literature synopsis. University of Lethbridge. Retrieved from https://education.alberta.ca/apps/aisi/literature/pdfs/FINAL_Professional_Learning_Communities.pdf

DuFour, R., DuFour, R., \& Eaker, R. (2008). Revisiting professional learning communities at work: New insights for improving schools. Bloomington, IN: Solution Tree.

DuFour, R., DuFour, R., Eaker, R., \& Many, T. (2006). Learning by doing: A handbook for professional learning communities that work. Bloomington, IN: Solution Tree.

Duling, K. S. (2012). The principal's role in supporting professional learning communities. Unpublished Doctoral dissertation, Kansas state university, USA. 
Al-Mahdy, Y. F. H., \& Sywelem, M. M. G.

Eaker, R., DuFour, R., \& DuFour, R. (2002). Getting started: Re-culturing schools to become professional learning communities. Bloomington, IN: National Educational Service.

Feger, S., Arruda, E., Pringle, R., \& Briggs, D. (2008). Professional learning communities: Key themes from the literature. The Education Alliance at Brown University, Providence, RI. Retrieved from http://www.brown.edu/academics/education-alliance/sites/brown.edu.academics.education-alliance/files /publications/PBS_PLC_Lit_Review.pdf

Gray, J. A. (2011). Professional learning communities and the role of enabling school structures and trust. Unpublished Doctoral dissertation, The University of Alabama, USA.

Harris, A. (2003). Teacher leadership as distributed leadership. School Leadership and Management, 23(3), 313-324. http://dx.doi.org/10.1080/1363243032000112801

Hartmann, S. (2008). The informal education sector in Egypt: Private tutoring between state, market, and civil society. Retrieved from http://www.ifeas.uni-mainz.de/workingpapers/AP88.pdf

Hefner, J. F. (2011). A case study of a professional learning community: An investigation of sustainability with a rural elementary school. Unpublished Doctoral dissertation, Appalachian State University, USA.

Hipp, K., \& Huffman, J. (2002). Documenting and examining practices in creative learning communities: Exemplars and non-exemplars. Retrieved from http://files.eric.ed.gov/fulltext/ED468685.pdf

Hipp, K., \& Huffman, J. (2003). Professional learning communities: Assessment-development-effects. Retrieved from http://files.eric.ed.gov/fulltext/ED482255.pdf

Hord, S. (1995). Learning together, leading together: Changing schools through professional learning communities. New York, NY: Teachers College Press.

Hord, S. M. (1997). Professional learning communities: Communities of continuous inquiry and improvement. Austin, TX: Southwest Educational Development Laboratory.

Hord, S. M., \& Sommers, W. A. (2008). Leading professional learning communities: Voices from research and practice. Thousand Oaks, CA: Corwin Press.

Huffman, J., \& Hipp, K. (2003). Re-culturing schools as professional learning communities. Lanham, MD: Scarecrow Education.

Ibrahim, A., Al-Kaabi, A., \& El-Zaatari, W. (2013). Teacher resistance to educational change in the United Arab Emirates, International Journal of Research Studies in Education, 2(3), 25-36. http://dx.doi.org/10.5861/ijrse.2013.254

Klieme, E., \& Vieluf, S. (2009). Teaching practices, teachers' beliefs and attitudes. In OECD (Ed.), Creating effective teaching and learning environments: First results from TALIS (pp. 87-135). Retrieved from http://www.oecd.org/berlin/43541655.pdf

Krafft, C. (2012). Challenges facing the Egyptian education system: Access, quality and inequality. Retrieved from http://www.popcouncil.org/uploads/pdfs/2012PGY_SYPEPolicyBrief2.pdf

Leithwood, K., \& Riehl, C. (2003). What we know about successful school leadership. Retrieved from http://dcbsimpson.com/randd-leithwood-successful-leadership.pdf

Leonard, L., \& Leonard, P. (2003). The continuing trouble with collaboration: teachers talk. Current issues in education, 6(1), 1-9.

Literacy and Numeracy Secretariat. (2007). Professional learning communities: A model for Ontario schools. Retrieved from http://www.edu.gov.on.ca/eng/literacynumeracy/inspire/research/PLC.pdf

Little, J. W. (2002). Professional community and the problem of high school reform. International Journal of Educational Research, 37(8), 693-714. http://dx.doi.org/10.1016/S0883-0355(03)00066-1

Loveluck, L. (2012). Education in Egypt: Key challenges: Retrieved from http://www.chathamhouse.org/sites/files/chathamhouse/public/Research/Middle\%20East/0312egyptedu background.pdf

Menshawy, B. (2012). School effects on educational attainment in Egypt. Retrieved from http://www.nottingham.ac.uk/credit/documents/papers/12-05.pdf

Morrissey, M. (2000). Professional learning communities: An ongoing exploration. Austin, TX: Southwest Educational Development Laboratory.

Morrow, J. R. (2010). Teachers' perceptions of professional learning communities as opportunities for promoting 
Teachers' perspectives on professional learning communities in some Arab countries

professional growth. Unpublished Doctoral dissertation, Appalachian State University, USA.

Newmann, Fred M. (1996). Authentic achievement: Restructuring schools for intellectual quality. San Francisco: Jossey - Bass Publishers.

OECD. (2010). Reviews of national policies for education: higher education in Egypt. Retrieved from http://www.oecd.org/dataoecd/39/34/44820471.pdf

Olivier, D. F., Hipp, K. K., \& Huffman, J. B. (2010). Assessing and analyzing schools. In K. K. Hipp \& J. B. Huffman (Eds.), Demystifying professional learning communities: School leadership at its best (pp. 29-42). Lanham, MD: Rowman \& Littlefield Education.

Pancake, A., \& Moller, G. (2002). Professional learning communities: a synthesis of a five- year study. The Annual Meeting of the American Educational Research Association, New Orleans, Louisiana.

Schmoker, M. (2006). Results now: How we can achieve unprecedented improvements in teaching and learning. Alexandria, VA: Association for Supervision and Curriculum Development.

Senge, P. M. (1990). The fifth discipline: The art and practice of the learning organization. New York, NY: Doubleday.

Stoll, L., \& Louis, K. S. (2007). Professional learning communities: Divergence, depth, and dilemmas. Berkshire, England: Open University Press.

Stoll, L., Bolam, R., McMahon, A., Wallace, M., \& Thomas, S. (2006). Professional learning communities: A review of the literature. Journal of Educational Change, 7(4), 221-258. http://dx.doi.org/10.1007/s10833-006-0001-8

Taylor, J. Y. (2011). Teachers' perceptions of professional learning communities in public schools on Saipan. Unpublished Doctoral dissertation, Pepperdine University, USA.

UNESCO, (2010). Egypt: World data on education. International Bureau of Education. Retrieved from http://www.ibe.unesco.org/fileadmin/user_upload/Publications/WDE/2010/pdf-versions/Egypt.pdf

Vescio, V., Ross, D., \& Adams, A. (2008). A review of research on the impact of professional learning communities on teaching practice and student learning. Teaching and Teacher Education, 24(1), 80-91. http://dx.doi.org/10.1016/j.tate.2007.01.004

Wells, C., \& Feun. L. (2007). Implementation of learning community principles: A study of six schools. NASSP Bulletin, 19(2), 141-160. http://dx.doi.org/10.1177/0192636507302085

Young, M. (2002). The national commission for the advancement of educational leadership preparation: an introduction. Educational Administration Quarterly, 38(2), 130-136. http://dx.doi.org/10.1177/0013161x02382002 
